\title{
Chronology OF ITALiAN Political Events, 2006
}

\section{January}

1 With the exception in particular of Rifondazione Comunista (RC, Communist Refoundation) and the Lega Nord (LN, Northern League) and, to a lesser extent, the Partito dei Comunisti Italiani (PdCI, Party of Italian Communists) and the Partito Radicale (Radical Party), the political parties express their admiration for the end-of-year address by the president of the Republic, Carlo Azeglio Ciampi.

The "gas war" breaks out between Russia and Ukraine.

2 The spokesperson for Piero Fassino, secretary of the Democratici di Sinistra (DS, Left Democrats), criticizes the newspaper Il Giornale for publishing wiretap transcripts of conversations between Fassino and the president of Unipol, Giovanni Consorte, and calls on the president of the Chamber of Deputies to take action.

The Ente Nazionale Idrocarburi (ENI, National Hydrocarbon Corporation) announces a 25 percent reduction in natural gas imports from Russia.

3 The president of the Senate, Marcello Pera, calls for urgent reform of the laws regulating wiretapping. Justice Minister Roberto Castelli sends inspectors to the Milan district attorney's office to investigate the role of magistrates in leaking information from the Unipol case.

4 In a letter to the newspaper La Stampa, Romano Prodi speaks out on the Unipol case, saying, "For some time, there has been a level of closeness between politics and economic institutions that, in certain instances, has been excessive."

Consorte is accused of criminal association. 
5 Silvio Berlusconi launches an attack on the cooperatives, saying that "they do not pay their taxes" and accusing them of using their profits to finance the parties of the left.

7 Members of the Radical Party hold hunger strikes and sit-ins in front of the Chamber of Deputies in support of the amnesty law, which is about to be discussed in Parliament.

10 The Bank of Italy rules against the Unipol takeover offer for the Banca Nazionale del Lavoro (BNL) on the grounds that Unipol "does not possess a satisfactory level of assets."

The first draft of Prodi's manifesto is released.

11 The DS leadership votes unanimously in favor of a position paper by Fassino, which deals with the question of the relationship between politics and business.

On the television show Porta a Porta, Berlusconi announces that he is going to provide prosecutors with information regarding the role of the DS in the BNL-Unipol case.

Disputes arise within the center-right following the rejection by Forza Italia (FI) of a proposal by Alleanza Nazionale (AN, National Alliance) to reform the ways in which soccer television rights are sold.

12 Berlusconi gives public prosecutors in Rome the names of those DS members who allegedly tried to convince BNL shareholders to sell to Unipol.

The Chamber of Deputies rejects the proposals for an amnesty law (vetoed by the DS and the Margherita) and for a pardon bill (vetoed by FI).

The Pecorella law reforming appeal procedures is definitively approved.

14 Businessman Diego Della Valle's comment that he "cannot wait until the prime minister is out of office" causes controversy.

The "Tutti in Pacs" rally in Rome in support of civil unions attracts 50,000 participants but divides the center-left. In Milan, 100,000 people attend a demonstration in favor of maintaining the abortion law.

15 Prodi repeats his appeal for the creation as soon as possible of a Democratic Party (Partito Democratico), which will build on "the spirit of the primaries."

Berlusconi calls on the DS to comment on the "€50 million obtained by Consorte in the public takeover bid for Telecom."

16 The new governor of the Bank of Italy, Mario Draghi, takes office.

Berlusconi accuses Prodi of having met the president of the Generali group, Antoine Bernheim, when the Unipol takeover bid was in full sway. 
Members of the metalworkers union block traffic on the highways to protest the delay of their contract renewal, which has been going on for a year.

18 Public prosecutors in Rome hear evidence from Bernheim and Tarak Ben Ammar, who both deny having been put under pressure by center-left politicians to sell their BNL shares to Unipol.

There are disputes among the parties over Berlusconi's frequent appearances on television.

19 Defense Minister Antonio Martino announces that the first reduction in the troop numbers in Iraq will take place in June and that Italian forces will have been fully withdrawn from the country by the end of December 2006.

Agreement is reached on a new contract for metalworkers.

20 President Ciampi sends the Pecorella law back to Parliament on the grounds that it has "clearly unconstitutional aspects."

Berlusconi requests that the dissolution of Parliament (scheduled for 29 January) be postponed for a week in order to complete various legislative procedures. The opposition claims that this is a ploy designed to delay the enactment of the par condicio rule.

22 The meeting between Ciampi and Berlusconi does not result in a definitive date for the dissolution of Parliament.

23 Berlusconi states that "if we do not have a further fifteen days before the dissolution of Parliament, the general election could take place in May."

Cardinal Camillo Ruini, president of the Italian Episcopal Conference, announces that the Church will not take sides in the forthcoming general election.

24 Agreement is reached on the date for the dissolution of Parliament, which will take place on 11 February.

The law on legitimate defense is approved amid criticisms from the opposition that it represents a "return to the Far West."

25 The government announces the key measures it intends to approve before the dissolution of Parliament. Berlusconi assures that the general election will take place on 9 April.

Claudio Scajola, the minister for productive activities, introduces a security plan to cope with the gas crisis.

27 During the inauguration of the judicial year, the president of the Court of Cassation, Nicola Marvulli, says that the laws passed since 2001 have hindered the "efficiency of magistrates."

28 Ciampi writes to the president of the watchdog committee of the RAI (Radio Televisione Italiana), requesting that the par condicio rule be applied immediately rather than waiting for the dissolution of Parliament. 
29 Over 80,000 people vote in primaries in Milan, as a result of which Bruno Ferrante is chosen as the center-left's mayoral candidate.

30 The president of the Chamber of Deputies and the leading member of the Unione dei Democratici Cristiani e di Centro (UDC, Union of Christian Democrats and Center Democrats), Pier Ferdinando Casini, agrees with Ciampi's call for the immediate application of the par condicio rule. According to Marcello Pera, however, Ciampi's request is not binding.

31 Berlusconi claims that magistrates are hushing up the findings of investigations into the role of the DS in the Unipol case.

Prodi says that his manifesto will include proposals for tax cuts.

\section{February}

1 The law on appeals sent back by Ciampi is approved, with a number of modifications, by the Chamber of Deputies.

Prodi announces that if the center-left wins the general election, his government will withdraw Italy's troops from Iraq.

2 Protests erupt around the world over cartoons published by a Danish newspaper that are considered blasphemous by many Muslims.

Prodi criticizes the measures approved the day before by the par condicio watchdog and says that he might not participate in face-to-face debates with Berlusconi.

3 Unipol-whose takeover bid for the BNL had been blocked by the Bank of Italy-sells its shares in the bank to the French group BNP-Paribas.

4 Berlusconi says that if Prodi does not participate in the face-toface debates, he might debate anyway with an empty chair.

7 Pier Ferdinando Casini and Massimo D'Alema (president of the DS) have a heated exchange about the "moral question" on the television show Ballarò.

Following threats to disrupt the Turin Winter Olympics issued by a number of groups opposed to the TAV (high-speed train) project in Piedmont, Ciampi calls for a sense of responsibility and greater collaboration between citizens and institutions.

8 Using a vote of confidence, the government succeeds in passing a law that abolishes the distinction between "soft" and "hard" drugs.

9 Berlusconi accuses the Communications Authority-which imposed sanctions on Mediaset for having violated the par condicio rule-of no longer acting as "guarantor, but as an instrument of political struggle." 
At a summit of the center-left Unione coalition, Francesco Rutelli (Margherita) and Emma Bonino (Radical Party) clash over the issues of civil unions (Pacs) and funding for private schools.

10 Berlusconi announces: "If I lose, I will lead the opposition. However, that will not happen as only Napoleon accomplished more than me."

Delegations from 16 regions present a request for a referendum on devolution at the Court of Cassation.

A dispute flares up within RC over heavily critical comments about Israel made by Marco Ferrando.

11 A decree dissolving Parliament is issued.

The Unione holds a convention to present its manifesto.

13 Following disputes over the lack of reference to the TAV in the center-left manifesto, Prodi claims that it is simply an "oversight" and that "the TAV will happen."

On the television show Matrix, Gianfranco Fini (leader of AN) and Massimo D'Alema accuse one another of housing extremists within their coalitions.

14 The Senate-whose powers are extended beyond the dissolution of Parliament decree-definitively approves the Pecorella law concerning appeals.

Controversy within the center-right arises over the general election candidatures of the neo-fascists Adriano Tilgher and Roberto Fiore of Alternativa Sociale (Social Alternative).

The European Commission expresses its approval for measures designed to reduce the public deficit below 3 percent in 2007 .

15 Fini and Casini veto the inclusion of Tilgher and Fiore as candidates of the center-right coalition.

Roberto Calderoli (LN) appears on television wearing a T-shirt displaying the Danish cartoons that feature caricatures of the prophet Mohammed.

16 The European Parliament (EP) approves the Bolkstein directive on liberalizations. Italian parties that are members of the same coalitions nationally vote differently from one another in the EP.

Berlusconi presents the results of a survey conducted by an American polling agency, according to which the center-right and center-left are neck and neck.

17 The Italian consulate in Bengasi (Libya) is attacked by a crowd of demonstrators following Calderoli's actions on television two days earlier. Police intervention results in numerous fatalities. Berlusconi declares that Calderoli "must resign immediately."

Agreement is reached between the center-right coalition the Casa delle Libertà (CdL, House of Freedoms) and Alessandra 
Mussolini. The candidatures of Tilgher and Fiore are withdrawn, and more "presentable" members of Alternativa Sociale are chosen instead. Prodi promises to reduce the ICI (imposta comunale sugli immobili, local property tax) if the center-left wins the general election.

The secretary of RC, Fausto Bertinotti, announces the exclusion of Marco Ferrando from the party's list of candidates.

18 Calderoli resigns as minister for institutional reforms and devolution. The Lega threatens to withdraw from the CdL alliance.

Fini visits the main mosque in Rome, where he gives a speech before an audience including ambassadors from Arab countries.

Leading figures from the PdCI and the Greens attend a march in support of Palestinians. Angry reactions from various parts of the political world are provoked by the slogan "10, 100, 1,000 Nassiriyas" and the burning of Israeli flags.

19 Disputes within the center-left follow the march in Rome. Centerright politicians also express heavy criticism of the event.

21 Berlusconi speaks on the Arab television station Al Jazeera and states that relations with Libya are calm.

Prodi promises families a $€ 2,500$ subsidy for every child under the age of 3 .

22 Fini blames Calderoli for the attacks in Libya. The LN responds that Fini's stance is "unacceptable."

23 Berlusconi promises extra benefits for those over the age of 70 .

24 The CdL presents the 10 points of its manifesto.

Disputes ensue over the television "duels" between Prodi and Berlusconi. The center-left leader threatens not to participate if Berlusconi does not forego his planned press conference at the end of the campaign.

25 The French prime minister, Dominique de Villepin, announces the merger between Suez-for which the Ente Nazionale per l'energia Elettrica (ENEL, Italian National Electricity Board) had launched a takeover bid-and Gaz de France.

26 The Italian government asks the European Union (EU) to intervene in the Suez-Gaz de France merger.

28 Finance and Economy Minister Giulio Tremonti and EU Competition Commissioner Neelie Kroes meet to discuss the Suez-ENEL case.

George W. Bush meets Berlusconi in Washington, DC. Bush describes Berlusconi as a "strong leader" who "has given Italy stability."

Prodi speaks of the prospect of a "draw" at the forthcoming general election and says that should this happen, a new general election would have to be held. 


\section{March}

1 Berlusconi addresses the United States Congress.

The 15th congress of the Confederazione Generale Italiana del Lavoro (CGIL-Italian General Confederation of Labor) opens. The CGIL secretary, Guglielmo Epifani, criticizes the government and speaks of a long-term pact with the Unione.

3 At the CGIL congress, Prodi stresses the need to relaunch the concertation dialogue process between social partners.

4 Fini agrees with Prodi that in the event of a draw, a new general election would have to be held

6 Berlusconi attacks Luca Cordero di Montezemolo, president of Confindustria (Confederation of Italian Industry), for having criticized the government and says "he should speak in his own name, not in that of all Italian industrialists."

8 Controversy follows the publication of an editorial by Paolo Mieli in the newspaper Corriere della Sera calling for a center-left victory in the general election.

Prodi confirms that he will participate in face-to-face debates following Berlusconi's agreement to forego the end-of-campaign press conference.

Prodi announces that the center-left will reintroduce the inheritance tax, but only for wealthy families.

Sixteen arrests are made as part of the investigations into the "Laziogate" scandal (illegal wiretaps conducted during the 2005 regional election in Lazio).

9 The former president of the Lazio region and current health minister, Francesco Storace, is implicated in "Laziogate." He responds that the accusations are "lies."

The leader of the Lega Nord, Umberto Bossi, says that if the center-left wins the general election, the Lega will no longer view its alliance with the CdL as binding.

10 Storace resigns as health minister.

The Milan district attorney's office requests Berlusconi's committal for trial regarding the subornation of David Mills, a witness in two 1997 trials that involved Berlusconi.

11 Efforts by a group of far-left activists to halt a far-right march in Milan result in violence.

Berlusconi refuses to accept the resignation of Nicolò Pollari, head of the Servizio per le Informazioni e la Sicurezza Militare (SISMI, Military Intelligence and Security Service). Pollari had offered to resign following the "Laziogate" scandal. 
12 Berlusconi walks out of a television interview with Lucia Annunziata, accusing the presenter of not letting him speak.

13 A summit takes place between Tremonti and his French counterpart, Thierry Breton, to discuss the Suez-Gaz de France case. The two sides continue to disagree.

14 The first face-to-face television debate between Prodi and Berlusconi is broadcast.

15 Calderoli defines the new electoral law, which his ministry had been responsible for, as "hogwash."

16 After the violent scenes on 11 March, an anti-violence rally is held in Milan. Prodi and Fassino decide not to participate on the grounds that it would be "misconstrued."

20 A dispute arises between Berlusconi and Confindustria. A communiqué from Montezemolo accuses Berlusconi of trying to "delegitimize" the organization. Berlusconi responds that the grassroots of Confindustria supports him and that Montezemolo is isolated.

22 Berlusconi attacks the center-left, accusing it of wanting to increase taxes on BOTs (buoni ordinari del tesoro, ordinary treasury bonds). Referring to the protests against him in Genoa the previous day, he claims that the opposition is using organized violence.

23 With only former president Antonio D'Amato voting in opposition, the Confindustria board supports Montezemolo's stance of "autonomy" in relation to politics and the government.

24 Ciampi calls on the two coalitions to moderate their tone in the election campaign.

At an EU summit of heads of state and government, French President Jacques Chirac rejects accusations of protectionism in relation to the ENEL takeover bid for Suez.

25 Berlusconi again claims the center-left will increase taxes. Prodi denies the charge, accusing the CdL of "spreading fear."

26 Prodi promises to reintroduce a majoritarian electoral system and a conflict of interest law.

27 Disputes erupt over the leadership within the center-right. Fini reaffirms that the leader of the party that receives the most votes will become prime minister.

Berlusconi proposes to remove taxes on overtime and accuses the center-left of wanting to take his television channels away from him.

28 Berlusconi's claim that during Mao's time in power in China "they boiled babies and used them to fertilize fields" provokes an official complaint from the Chinese Ministry of Foreign Affairs.

29 Prodi accuses Tremonti of "political delinquency" for his comments on the increase in pension contributions envisaged by the center-left. 
Berlusconi urges the creation of a unified center-right party to be called Partito del popolo italiano (Party of the Italian People).

30 Prodi specifies that any tax increases on BOTs will affect only newly issued bonds.

\section{April}

1 Tremonti announces positive quarterly results. Prodi says that the center-right is leaving the country with "a burdensome inheritance."

2 In a television interview with Lucia Annunziata, Prodi says that his government will crack down on tax evasion and repeats his view that a new election would have to be held in the event of a draw.

3 In their second televised debate, Prodi promises to reduce employment taxes, while Berlusconi vows to abolish the ICI.

4 Controversy is provoked by Berlusconi's comment: "I have too much respect for the intelligence of the Italian people to believe that there are really so many assholes out there prepared to vote against their own interests."

5 Fausto Bertinotti (RC) proposes abolishing the ICI for those with lower incomes.

6 Berlusconi criticizes the Milan magistrates for accusing him of corruption in the David Mills case. He also refers to the need for United Nations (UN) observers to guard against possible electoral fraud.

7 On the final day of campaigning, Berlusconi asserts that the election represents a clash similar to that in 1948. Prodi sums up his objectives as "greater prosperity and greater equality."

9 The first day of voting in the general election sees a turnout of 66.5 percent.

10 On the second day of the general election, there is a long wait for definitive results after the polls close, leading to disputes and uncertainty. Based on exit polls, the center-left announces its victory party in Rome. However, the celebration is postponed several times over the course of the evening as the result appears in doubt. The party finally takes place late at night when the narrow center-left victory is confirmed.

11 Berlusconi calls for a "close check" of dubious votes and indicates his willingness to participate in a "grand coalition." This is rejected by Prodi and the Unione.

Ciampi announces that his successor as president will swear in the next prime minister.

The Mafia boss Bernardo Provenzano is arrested in Sicily after 43 years as a fugitive from justice. 
12 Berlusconi accuses the center-left of electoral fraud and calls for rechecking all ballot papers that had been declared void.

15 In a letter to the Corriere della Sera, Berlusconi says that "there are neither losers nor winners ... we should not dismiss the possibility of a partial and temporary agreement to work together in order to tackle the pressing institutional, economic, and international commitments of the country."

16 Calderoli contests the attribution of votes for the Lega alleanza lombarda to the Unione, stating that "they should not be taken into account as that party stood in only one constituency." $\mathrm{He}$ claims that if these votes were subtracted from the Unione total, the CdL would be ahead in the Chamber of Deputies election by approximately 20,000 votes.

17 A meeting takes places between Prodi and Bertinotti. The RC leader agrees to allow his name go forward as a candidate for the presidency of the Chamber of Deputies. Vannino Chiti argues that the presidency of the Chamber should go to a member of the DS, as they are the largest party in the Unione coalition.

Ciampi rules out the possibility of his standing for a second term as president of the Republic.

19 The Court of Cassation confirms the Unione's victory by 24,755 votes in the Chamber of Deputies election.

The Unione proposes Franco Marini as its candidate for president of the Senate, while some in the CdL put forward Giulio Andreotti for the post.

Heated disputes take place within the center-left over its candidate for president of the Chamber of Deputies.

20 Tensions persist within the center-left over its candidate for president of the Chamber of Deputies. Fassino and D'Alema write to Prodi, asking him to decide quickly and pointing out that the candidature of Bertinotti risks creating "a dangerous division."

21 D'Alema withdraws his candidature for the presidency of the Chamber of Deputies.

22 Andreotti accepts the center-right candidature for president of the Senate, although the Lega Nord has not said that it will support him.

23 The boards of Autostrade (National Highways) and Abertis approve the merger of the two companies. Various members of the center-left express reservations about the move.

24 Run-off contests take place in the Friuli-Venezia Giulia local elections. The center-right wins the municipal contest in Trieste, while the center-left wins the provincial elections in Trieste and Gorizia. 
25 One hundred thousand people participate in the Liberation Day celebrations in Milan. Controversy is provoked by the heckling of the center-right mayoral candidate, Letizia Moratti (who leaves the march), and the burning of Israeli flags.

In his traditional Liberation Day address, Ciampi defines the Constitution as his "civic bible." He calls on the political parties to "leave behind the bitterness of the election campaign" and to "work together constructively on the major political decisions."

27 Prodi reiterates his intention to set a timetable for withdrawal from Iraq.

29 The first round of voting occurs in the elections for the presidents of the Chamber of Deputies and the Senate.

30 Fausto Bertinotti is elected president of the Chamber of Deputies, while Franco Marini eventually wins the vote to become president of the Senate.

Discussions take place among the political parties over who should be the next president of the Republic and when the new government should take office. The principal names mentioned are Gianni Letta, Giuliano Amato, Massimo D’Alema, and Carlo Azeglio Ciampi.

31 The DS suggest D'Alema as a possible candidate for president of the Republic. Forza Italia expresses strong opposition.

\section{May}

2 The CdL officially proposes Ciampi for a second term as president.

3 Ciampi says that he is not willing to stand again.

4 Prodi and Berlusconi meet to discuss the question of the presidency of the Republic. Prodi suggests D'Alema, while Berlusconi proposes Letta.

The Court of Cassation acquits Renato Squillante in the IMI-SIR case and reduces Cesare Previti's sentence from seven to six years.

5 The Unione leadership considers the candidate for the presidency. The Rosa nel pugno and parts of the Margherita express reservations about D'Alema.

Berlusconi reiterates his opposition to D'Alema as president.

Luciano Moggi, general manager of the Juventus soccer team, is investigated by the district attorney's office in Naples for having influenced the outcome of matches and for having had secret contacts with referees (as revealed by wiretaps).

7 The center-right puts forward four names for the presidency of the Republic (Franco Marini, Mario Monti, Lamberto Dini, and 
Giuliano Amato). The center-left responds by proposing, in place of D’Alema, Giorgio Napolitano (deemed “inadmissible” by FI).

8 The first round of voting for the presidency of the Republic takes place. AN and the UDC indicate that they would be open to Napolitano.

The EU's commissioner for economic and monetary affairs, Joaquín Almunia, calls on the incoming government to "implement all the measures contained in the 2006 budget and, if necessary, to add any other measures in order to meet the deficit reduction target."

Franco Carraro resigns as president of Federazione Italiana Giuoco Calcio (FIGC, Italian Soccer Federation).

9 The second and third rounds of voting fail to produce a winner in the presidential election. The majority of votes are blank. Berlusconi declares that "the conditions do not exist for an agreement."

10 Napolitano is elected president of the Republic in the fourth round of voting. Apart from the Lega Nord, which votes for Bossi, most members of the CdL cast blank votes.

12 At the center-left leadership meeting to decide the composition of the cabinet, D'Alema argues that there should be just one deputy prime minister, while Rutelli wants two.

13 The center-left continues negotiations over the composition of the cabinet. D'Alema accepts the proposal for two deputy prime ministers.

15 Napolitano delivers his inaugural address to Parliament. He vows to be "the president of everyone" and refers to the significance of the resistance in Italian history. He also underlines the importance of Europe and stresses the need for integrating immigrants. Of the CdL parties, AN and UDC express positive views on the speech, while FI and LN convey generally cold or negative responses.

Guido Rossi is appointed commissioner of the FIGC.

16 The president of the Republic invites Prodi to form a government.

In his last meeting with journalists as prime minister, Berlusconi repeats his call for a recount of general election ballot papers and says that he will be "the next candidate for prime minister of the Partito della Libertà [Freedom Party], which will be created by the spring of 2007."

17 Prodi presents his government, which is made up of 25 ministers (including 9 from the DS and 6 from the Margherita). The new foreign affairs minister, Massimo D'Alema, and the minister for culture, Francesco Rutelli, will serve as deputy prime ministers. The amount of ministerial portfolios and the small number of women in the cabinet provoke criticism. 
18 In his speech to the Senate during the vote on the new government, Prodi declares that Italy will leave Iraq as soon as it is technically possible. He also promises to revise the Biagi law, modify the electoral system, and introduce a new conflict of interest bill, which will be "more rigorous than the current one." He adds that the government will introduce economic policies that will "shake up" the country and resolves to fight tax evasion.

19 The Senate votes in the new government. The center-right condemns the Senators-for-Life for siding with the government.

In a press conference at the end of the assembly of Italian bishops, Ruini repeats the Church's opposition to non-traditional families and expresses his appreciation for the creation of a Family Ministry. He also announces that the Church will not take sides in the forthcoming constitutional referendum.

20 The Pope speaks out for the third time in several days on ethical matters and repeats the Church's positions on civil unions, artificial insemination, and the teaching of religion in state schools.

21 During a visit to Ventotene, Napolitano calls for greater dialogue between the two coalitions. However, Prodi and Berlusconi both respond that the conditions do not exist for this.

22 Berlusconi criticizes the government for having broken up several ministries and notes that ministers were sworn in before the cabinet meeting that officially decided these divisions. The president of the Republic, in an official communiqué, replies that everything "was conducted with the greatest respect for the rules and according to standard practices ... no minister was sworn in improperly: those ministers who did not yet have a role attributed to them were sworn in as ministers without portfolio."

23 The Chamber of Deputies votes in the new government.

25 At Confindustria's annual assembly, Montezemolo calls on the government to make "courageous decisions" regarding tax reductions and cuts in public spending. He also urges it to keep the Biagi law.

Berlusconi says that the center-right is ready to take to the streets to bring down the government.

26 Prodi writes to the presidents of the two houses of Parliament, outlining his government's agenda. Among the first measures is the revision of various laws approved by the previous government such as the justice reform, the introduction of which is to be postponed.

27 Interior Minister Giuliano Amato announces that the government may raise the 2006 quotas for legal immigrants and will re-examine some of the requests rejected under the previous quota system.

29 Walter Veltroni (Rome), Letizia Moratti (Milan), Rosa Russo Iervolino (Naples), and Sergio Chiamparino (Turin) all win first-round 
victories in the mayoral elections. Salvatore Cuffaro is re-elected president of the region of Sicily.

30 Controversy follows the announcement by Fabio Mussi, the minister for university and research, that Italy will no longer support the "ethical declaration" of the EU against stem-cell research.

Rumors circulate that Berlusconi is changing his strategy. Following the broadly negative local election results, FI will back a "yes" vote in the constitutional referendum but will not seek to portray it as a verdict on the government.

31 In his first annual "Final Considerations" speech, the governor of the Bank of Italy, Mario Draghi, stresses the importance of growth once the public accounts have been put in order. He also underlines the need for greater flexibility and the necessity of increasing the retirement age.

Napolitano signs a pardon for Ovidio Bompressi.

Prodi expresses disapproval at Mussi's stance in favor of stemcell research.

\section{June}

1 A cabinet directive triggers increases in regional business taxes (IRAP) and personal income taxes (IRPEF) in six regions (Abruzzo, Molise, Sicily, Campania, Liguria, and Lazio), all of which have failed to respect health-spending limits.

2 During a visit to Regina Coeli prison in Rome, Justice Minister Clemente Mastella says that he will ask Parliament to approve an amnesty bill. Prodi confirms that this is government policy.

While attending a military parade, Bertinotti is heckled by protestors from a pacifist counter-demonstration.

Prodi and Tony Blair meet to discuss Italy's withdrawal from Iraq.

3 AN and LN oppose Mastella's amnesty proposal. FI supports it and calls for financial crimes to be included.

5 An attack close to Nassiriya in Iraq kills one Italian soldier and injures four others.

Inspections of immigrant holding centers begin following several outbreaks of violence.

At a government retreat in San Martino in Campo, Prodi asks his ministers to reduce their official escorts and personal staff.

6 Speaking in the Chamber of Deputies about the attack in Nassiriya, Prodi says that plans for Italy's withdrawal from Iraq have not changed. 
With regard to the votes for the presidents of the parliamentary commissions, the center-left obtains all 14 in the Chamber of Deputies and 11 out of 12 in the Senate (the Industrial Commission goes to Aldo Scarabosio of the CdL). The vote for president of the Defense Commission is postponed.

$7 \quad \mathrm{RC}$ requests an explanation following the failure of Lidia Menapace to be elected president of the Defense Commission in the Senate.

9 With the nomination of three new junior ministers, the government now has 102 members.

In a meeting with Prodi and D'Alema, NATO's secretary general, Jap de Hoop Scheffer, asks Italy to send more troops to Afghanistan.

The cabinet announces a bill to block the Castelli justice reform. Antonio Di Pietro disagrees as he would prefer a decree law, which would take effect immediately.

10 The Greens, RC, and the PdCI criticize the comments of NATO's secretary general.

Fini says that it is useless for the opposition to hope that they will be able to dislodge the government. He raises the issue of the CdL leadership and states that the contest will not be between Prodi and Berlusconi in 2011.

Mastella says that he hopes the government can reach agreement with the opposition on the justice question.

11 Defense Minister Arturo Parisi affirms that Italian troops will leave Iraq "as soon as possible" and that they will not remain even as support for an eventual civil humanitarian mission. As regards Afghanistan, however, he says that "we will decide together with our allies."

12 A meeting takes place between Prodi, the economy ministers, and the unions. Trade union leaders say they have received reassurances from the government.

At a meeting of EU foreign ministers, D'Alema says that the government will continue to support Turkish accession.

Municipal election run-off ballots post the following results. The center-left wins in Caserta, Catanzaro, Rovigo, and Salerno. The center-right takes Belluno and wins first-round victories in the province of Trapani and the Cagliari city council.

13 In the Senate, the CdL requests a debate and vote on three motions opposing Mussi's decision to withdraw Italian support for the European ethical declaration on stem-cell research. The Unione-including the Catholics of the Margherita-maintains a united front, and the request is rejected.

14 The government announces its first recourse to a confidence vote for the decree reorganizing the competencies of ministries. 
Tommaso Padoa Schioppa tells Parliament that the public finances are in a worse condition than in 1992.

Speaking on the forthcoming referendum, Bossi says: "If the 'no' vote wins, the current government will not make any reforms to the Constitution ... We will have to explore other avenues, as it will not be possible to change anything democratically."

15 Berlusconi defends Bossi for his comments on the referendum, while AN and the UDC distance themselves.

The European Parliament approves the European Commission proposal to finance eight projects involving stem-cell experiments. CdL members of the European Parliament and six from the Margherita vote against the measure.

16 Vittorio Emanuele di Savoia is arrested in connection with a prostitution and corruption scandal, following a warrant from the district attorney's office in Potenza.

In a meeting with US Secretary of State Condoleezza Rice, D'Alema presents Italian post-withdrawal proposals for Iraq.

Ciampi says that he will vote "no" in the constitutional referendum. The CdL expresses criticism.

17 Prodi announces that after the referendum, the government "will work toward an agreed, considered, and broad reform."

18 Gianfranco Fini defends his spokesperson from accusations, calling for regulations that will put an end to the "media persecution resulting from wiretaps." Mastella announces a bill limiting the use of wiretaps.

Disputes within the CdL follow the announcement by the UDC that it is willing to vote with the Unione on the proposal to release funds for the Italian mission in Afghanistan. FI and AN disagree.

19 Prodi says that the television stations have been biased in their coverage of the referendum campaign.

Berlusconi calls for a "yes" vote in the referendum as a protest against the government.

20 Napolitano encourages all citizens to vote in the referendum, stating that "whatever the result, the question of reform should be discussed again in Parliament in order to ensure the widest possible consensus."

There is disagreement within the center-left on Afghanistan. The radical left criticizes Parisi for raising the possibility of increasing the Italian contingent in the country.

21 A center-right rally in Rome is held to support a "yes" vote in the referendum.

The Communications Authority issues a warning to Mediaset for having provided biased information about the referendum. 
The RAI board appoints Claudio Cappon director of RAI.

22 In the Calciopoli soccer scandal, Fiorentina, Juventus, Lazio, and AC Milan are all sent for trial, along with 26 individuals, including Adriano Galliani, who resigns as president of the Lega Calcio (soccer league).

Prodi announces that after a "no" victory in the forthcoming constitutional referendum, he will endeavor to reduce the number of deputies to a maximum of 400 .

23 Vannino Chiti, minister for relations with Parliament and institutional reforms, says that the government intends to change article 138 of the Constitution by introducing a higher quorum.

Berlusconi says that the CdL will not prop up the Unione on the Afghanistan vote.

24 Disagreements are present within the Unione on the mission in Afghanistan. A number of RC and PdCI senators declare that they will vote against the government.

26 The constitutional referendum delivers a 61.7 percent "no" victory. Berlusconi claims that a "historical opportunity has been missed." Bossi says that the Lega will continue its alliance with Berlusconi.

Amato suggests creating a convention to rewrite the Constitution.

27 The members of the Unione come to a general agreement on the mission in Afghanistan, but dissatisfaction persists among the PdCI, RC, and the Greens.

Bossi announces that the Lega's traditional Pontida meeting is to be postponed until after the summer.

28 The request to resort to a confidence vote on the decree dividing up ministries provokes clashes in the Senate. Livio Malan (FI) is ejected, but he refuses to leave for eight hours.

Eight Unione senators announce that they will vote against the government in the Afghanistan mission vote unless the funding decree contains "a clear reference to an exit strategy." The UDC says the party will vote with the government. In a meeting with UDC leaders, Berlusconi says, "We have the chance to send this government packing. Why are you helping it? A government has to have a common foreign policy, otherwise it is unsustainable."

29 At a meeting of the AN leadership, Fini says that, following the referendum, "the CdL as we knew it is over."

Napolitano calls for agreed appointments to the Magistrates' Governing Council and the Constitutional Court.

Prodi says that the TAV is an indispensable project, if Italy is to keep pace with the rest of Europe. 
Parisi comments that if all components of the Unione do not vote in favor of the Afghanistan mission funding bill, a new general election should be held.

The opposition announces a motion on funding for the Afghanistan mission and invites the governing majority to vote for it.

30 The cabinet approves new budgetary and liberalization measures. Protests are mounted by taxi drivers (who are among those categories affected) in several cities.

The cabinet unanimously approves the decree on further funds for the mission in Afghanistan.

\section{July}

1 Protests by taxi drivers and other sectors hit by the liberalizations decree continue. The government receives praise from consumer associations. The CdL expresses conflicting views.

Olivero Diliberto, leader of the PdCI, says that his party will not bring the government down in the Afghanistan vote.

At a meeting of the "Correntone" wing of the DS, Mussi says that he opposes the proposed Democratic Party and calls for a DS congress to discuss the matter in the fall.

2 In response to Mussi's comments, Fassino says that the congress will take place in 2007.

3 Protests by taxi drivers bring traffic to a standstill in numerous cities.

Napolitano holds meetings with Bossi and Berlusconi on the question of reforms.

Mastella expresses his opposition to the liberalization decrees, saying that they should be within his remit. He threatens to leave the government.

4 At the tribunal investigating the soccer scandal, the prosecution calls for the relegation of Juventus to the third division and severe penalties for the other teams involved.

The political parties agree on the election of eight lay members to the Magistrates' Governing Council.

5 Although they confirm their 11 July strike, taxi drivers suspend their protests following the announcement by Pierluigi Bersani, the minister for economic development, that he is willing to negotiate.

The second-ranked official at the SISMI, Marco Mancini, is arrested in connection with the CIA kidnapping of Abu Omar.

6 Amato says the Secret Services must be reformed. 
Berlusconi criticizes the government's liberalization program, saying that it represents the first step in a campaign of "fiscal and bureaucratic oppression."

Mastella criticizes the soccer scandal inquiry and calls for an amnesty in the event of an Italian victory in the World Cup final.

A parliamentary commission begins discussing the bill on "Italian participation in international missions."

Fini states that he is willing to support the government in the Afghanistan vote. However, he comments: "Given the measure is almost identical to that proposed by the CdL, I am curious to see how the government will explain it to the radical left."

The government outlines the contents of the DPEF (Economic and Financial Planning Document) to the trade unions, which view the envisaged cuts as excessive.

7 The government approves the DPEF. The minister for social solidarity, Paolo Ferrero (RC), does not vote.

After a meeting with Bersani, the taxi drivers cancel their strike scheduled for 11 July.

A meeting to discuss the Secret Services is held at Palazzo Chigi.

Berlusconi is sent for trial, along with Fedele Confalonieri and 12 others, in connection with the inquiry into the sale of television rights.

8 Montezemolo expresses his approval of the DPEF. Criticism from the Confederazione Italiana Sindacati Lavoratori (CISL, Italian Confederation of Workers Trade Unions). The CGIL praises the measures designed to combat tax evasion.

9 Italy wins the World Cup in Germany.

10 Following the World Cup victory, various politicians call for clemency in the soccer scandal investigations.

The UN asks Italy to make a bigger commitment in Afghanistan.

Padoa Schioppa presents the DPEF to the Eurozone group, which expresses its satisfaction. Joaquín Almunia, however, says that it must be followed by "concrete budgetary measures."

11 D'Alema says that he will resign if there is a shift in foreign policy.

12 Israel reacts to Hezbollah's killing of eight soldiers and its kidnapping of two others by attacking Lebanon.

Berlusconi criticizes the "shameful seesawing of the left" and says that the CdL will vote in favor of funding for the Afghanistan mission. D'Alema says he is willing to support the center-right amendments.

13 Napolitano warns the Unione that the vote on Afghanistan must be united, otherwise "it could create rather delicate political problems." 
Taxi drivers recommence their blockades to protest the liberalizations decree.

14 Soccer's Federal Court of Appeal orders Juventus to be relegated to the second division (with 30 penalty points) and strips its 2005 and 2006 league titles. There are also heavy penalties for Fiorentina, Lazio, and Milan.

15 At the G8 summit in St. Petersburg, Prodi and Bush discuss Italy's withdrawal from Iraq.

Prosecuting attorneys from Milan question the SISMI director, Nicolò Pollari, about the Abu Omar case. Pollari invokes the Official Secrets Act and refuses to respond.

16 The G8 summit reaches a compromise on the conflict in Lebanon, defining the release of the Israeli soldiers as a matter of priority. It calls on Hamas and Hezbollah to cease their attacks and on Israel to halt military operations.

Milan prosecutors ask the government to rule on whether Pollari can use the Official Secrets Act to avoid answering questions.

17 Following the request by UN Secretary-General Kofi Annan for an international peace force in Lebanon, Prodi says that Italy is willing to send troops.

Berlusconi criticizes the government for its "impartial" stance in the Israeli-Palestinian conflict.

18 D'Alema states that the Israeli response in Lebanon is legitimate but "disproportionate." He observes that the war in Iraq has failed to bring stability to the Middle East. Members of the center-right, in particular, express criticism.

Padoa Schioppa says that Italy will have to meet EU deficit limits in 2007 as the plan to postpone this goal until 2008 has been rejected by the EU.

19 In the Chamber of Deputies, the Afghanistan mission is approved with 549 votes in favor and 4 (from RC deputies) against. The CdL votes with the government.

According to the organizers, 93 percent of pharmacies participate in the lockout to protest the liberalizations decree.

The center-left motion on stem cells is approved in the Senate. The government commits to "supporting research that does not involve the destruction of embryos."

The European Commission investigates Italy for a breach of the rules and gives the Italian government two months to respond to charges that the Gasparri law hinders competition.

20 Israel agrees to the establishment of a humanitarian aid corridor in Lebanon as part of an aid plan backed by Italy. 
Disagreements arise within the center-left over the Senate vote on the Afghanistan mission. Nine senators from the Unione declare that they will vote against. D'Alema contends that it would be legitimate to use a vote of confidence, if necessary.

The newspaper Avvenire criticizes Catholic members of the government for their part in the compromise that led to the passing of the motion on stem-cell research.

21 In an interview with the Corriere della Sera, Prodi says that he is against the idea of broadening the governing coalition and states that if his government falls, the only option will be to hold a new general election.

The cabinet authorizes the use of a vote of confidence on the Afghanistan mission. Talks are held with center-left senators who have said they will vote against.

The cabinet reopens entry quotas for an additional 350,000 immigrants.

22 In a letter to the newspaper Il Messaggero, Berlusconi says that he will vote in favor of the Afghanistan mission.

23 The Israeli premier approves the dispatch of a European force to Lebanon.

24 While assuring that he does not intend to bring the government down, Di Pietro "suspends himself" from ministerial activities in protest over the proposals for a pardon bill. Bertinotti says the pardon bill is "an absolute priority" and, as such, must be approved by the end of the summer.

25 In the soccer scandal, the appeals board reduces the penalties that had been imposed.

Di Pietro and his supporters protest against the pardon bill.

Following a vote of confidence, the Senate approves a first reading of the Visco-Bersani decree, including budgetary and liberalization measures.

Bertinotti calls on the government to make less frequent recourse to decrees and expresses the hope that the center-left will be able to govern without depending on outside support.

Pollari's lawyers ask the district attorney's office in Milan to question those government members responsible for the Secret Services since 2001.

26 A summit in Rome on the Middle East and the conflict between Israel and Lebanon calls for the deployment of an international peace force and the opening of a humanitarian corridor as soon as possible. D'Alema says that Italy is willing to participate in an international force. 
27 The pardon bill is approved in the Chamber of Deputies (with Italia dei Valori, the Lega Nord, and some members of AN voting against). Tensions within the government mount between Di Pietro and Mastella.

With a vote of confidence, the Senate approves article 2 of the bill (regarding Afghanistan) on foreign missions. The CdL does not participate in the vote and contests the outcome, saying that there was not a quorum.

The governing body of the Bank of Italy approves its new statute, which provides for the expansion of its board of directors from four to five members.

28 With 161 votes in favor, the Senate approves a vote of confidence on the mission in Afghanistan. The center-right walks out.

29 The pardon bill is definitively approved by the Senate ( 245 votes in favor, 56 against, 6 abstentions). Both coalitions are internally divided over the issue. In the CdL, FI and the UDC are in favor, while AN (with a few exceptions) and the LN are against.

The government announces that Italy is willing to lead the international intervention force in Lebanon.

30 At a meeting with Condoleezza Rice, D'Alema says that the Israeli bombardment of Qana is unjustifiable.

31 In an interview with the Wall Street Journal, Montezemolo says that he has not yet seen "any real effort to reduce public spending."

The RC's secretary, Franco Giordano, criticizes those members of $\mathrm{RC}$ who voted against the government on Afghanistan and accuses them of having diminished the party's "bargaining power."

\section{August}

1 The Chamber of Deputies votes on the budgetary measures bill. The government makes recourse to a vote of confidence. With the exception of the UDC, the opposition walks out.

Nicola Mancino is unanimously elected vice-president of the Magistrates' Governing Council.

2 Speaking in the Chamber on the crisis in the Middle East, D'Alema says he is concerned that it could spread to the rest of the region and criticizes the Israeli government.

In the parliamentary debate on the budgetary measures bill, Berlusconi refers to a "tax police state" and to a Parliament "deprived of authority."

3 In the vote on the budgetary measures, the government is defeated twice on items presented by RC and FI. 
4 The government blocks the Autostrade-Abertis merger due to a conflict of interest.

Following an agreement between Di Pietro and Mastella, the cabinet approves a bill on wiretapping.

5 Abertis announces its intention to continue working toward a merger with Autostrade.

6 Pollari testifies before COPACO (Parliamentary Committee for the Intelligence and Security Services and for State Secret Control) on the Abu Omar case and repeats his claim that the Italian Secret Services did not assist CIA agents with the kidnapping.

7 Figures for June show an increase in tax revenue and a reduction in evasion. Both coalitions take credit.

$\mathrm{RC}$ says it intends to pursue the closure of temporary holding centers for immigrants.

8 A debate within the center-left follows the increase in tax revenue, with some sectors calling for a less stringent budget than previously envisaged. Prodi disagrees.

11 After several days of negotiations, the UN approves a peace plan for the Israel-Lebanon conflict. A force of $15,000 \mathrm{UN}$ troops is proposed.

12 Prodi says that Italy will participate in the Lebanon peace mission and that all political parties are in agreement with the UN plan.

13 The first details of Italy's involvement in Lebanon emerge. Italy will have the second largest contingent, after France. Berlusconi calls for clear rules of engagement and says that the CdL will act "responsibly."

16 Prodi reiterates Italy's commitment to the mission in Lebanon but calls on the UN to specify the rules of the mission.

18 Following a cabinet vote, the parliamentary Foreign Affairs and Defense Commission authorizes the government to take the necessary steps to implement United Nations Security Council Resolution 1701 on the mission in Lebanon. The Lega abstains.

19 Controversy follows the publication in several daily newspapers of a full-page statement by the Union of Islamic Communities and Organizations in Italy (UCOII), comparing Israeli actions in Lebanon to the Nazi atrocities in Italy.

20 At a meeting with Prodi, the Israeli prime minister, Ehud Olmert, asks Italy to lead the UN force.

21 At a meeting with Kofi Annan, Prodi says that Italy is willing to lead the multinational force.

22 After several boats carrying immigrants have sunk, the interior and justice ministers and police chiefs meet to discuss the illegal immigrant crisis. 
24 At a meeting of the Committee against Discrimination and AntiSemitism, Amato says that he will ask UCOII and other Islamic organizations to sign a charter affirming that they support the fundamental values of Italy.

25 A summit of foreign affairs ministers confirms that the EU will commit 7,000 troops to the Lebanon mission. Italy expresses its approval.

26 The boards of Banca Intesa and Sanpaolo unanimously approve the merger of the two banks.

27 In the run-up to the presentation of the budget, a dispute arises within the center-left between those who advocate cuts in public spending and those, like RC, who argue that the health and pensions sectors should not be touched and that measures should be spread out over two years.

28 The cabinet unanimously approves the decree regarding the peace mission in Lebanon. Italy will commit 2,500 troops.

At a meeting of the Italian Islamic Council, UCOII refuses to sign a condemnation of its newspaper statement.

29 Padoa Schioppa officially announces an expected budget of $€ 30$ billion and confirms that the deficit-GDP relationship will be reduced to 3 percent in 2007 .

Italian soldiers set off for Lebanon from Brindisi.

30 Disagreements arise over the issue of conflict of interest regulation following Prodi's announcement of imminent measures. FI says that it would be an "illiberal attempt to stop the opposition leader from participating in political life."

31 Padoa Schioppa presents the budget to the cabinet.

The Chiti draft paper on the conflict of interest question, containing a series of proposals by the minister for relations with Parliament and institutional reforms, is presented.

\section{September}

1 The trade unions express strong opposition to reforms increasing the retirement age.

2 The International Monetary Fund (IMF) says that Italy lacks a credible economic reform plan.

3 Napolitano calls for the parties to reopen dialogue on reforms and to behave more calmly toward one another.

4 The government outlines the main points of the budget to the unions. It refuses to exclude the possibility of pension reform being part of the budget, but affirms that any such reform will be done with ample consultation. 
5 The Organisation for Economic Co-operation and Development (OECD) and Confindustria revise their projections upwards for Italy's 2006 GDP.

Napolitano calls for reducing the amount of time that immigrants must wait to attain Italian citizenship.

6 The CISL says it is willing to discuss an increase in the pensionable age.

Change occurs at the top of the state railways. Following the resignation of Elio Catania, the Treasury appoints Innocenzo Cipolletta as president and Mauro Moretti as chief executive.

8 A bomb in Farah (Afghanistan) kills four Italian soldiers. RC, the PdCI, and the Greens urge Italy's withdrawal from Afghanistan.

9 Berlusconi announces his all-out opposition to "the only glaring conflict of interest in Italy: that between center-left local governments and the red co-ops." He also states that he no longer agrees with the objectives of the mission in Lebanon. Fini concurs, but Casini disagrees.

Prodi confirms the government's intention to set the capital gains tax at 20 percent. The opposition terms it "exorbitant."

10 Prodi charges that, by expressing doubts about the mission in Lebanon, the CdL is "assuming a huge responsibility." Berlusconi responds, saying, "My views on Lebanon were completely misrepresented. I never said we would vote against."

11 The board of Telecom Italia decides on the restructuring of the firm.

12 Prodi declares his "surprise" at Telecom's announcement, saying he was not informed.

13 Disagreement arises between Prodi and Marco Tronchetti Provera, president of Telecom, on the restructuring of the group.

The government sends a mission to China.

The board of RAI appoints Gianni Riotta as editor in chief of the RAI 1 news service.

14 Angelo Rovati, an adviser to the prime minister, says he was responsible for the controversial Telecom plan and that Prodi was unaware of it.

Padoa Schioppa meets union leaders and relaunches the concertation dialogue process. He calls for revising the 1993 development agreement.

With the exception of the LN members, the Foreign Affairs and Defense Commission unanimously approves the Lebanon mission.

15 Tronchetti Provera resigns as president of Telecom and is replaced by Guido Rossi.

The opposition demands that Prodi report to Parliament on the Telecom affair. Prodi declines. 
Mario Landolfi (AN) is appointed head of the RAI watchdog committee.

16 Bertinotti says he supports the idea of a parliamentary debate on government involvement in the Telecom affair. Berlusconi accuses the government of excessive intervention.

Speaking at a UDC meeting, Casini says that the party is not obliged to follow the CdL line now that it is no longer in government.

17 Fassino urges the construction of the Democratic Party as soon as possible and says that the Party of European Socialists (PES) in the European Parliament should serve as a reference point for it.

18 Rovati resigns as an adviser to the prime minister.

Speaking from the mission to China, Prodi says that he supports the cessation of the arms export embargo to the country.

Tax revenue figures for July are better than expected. Parts of the center-left call for a less stringent budget.

19 Prodi announces that he will deliver a report on the Telecom affair in the Chamber of Deputies on 28 September.

Amid controversy, Guido Rossi resigns as commissioner of the FIGC.

20 The district attorney's office in Milan issues twenty preventive detention orders relating to the wiretapping inquiry.

In his address to the General Assembly of the UN, Prodi calls for greater multilateralism. He also meets with the Iranian president, Mahmoud Ahmadinejad.

The Comitato Olimpico Nazionale Italiano (CONI, Italian National Olympic Committee) appoints Luca Pancalli as commissioner of the FIGC.

21 Following pressure from the CdL, Prodi says that he will also report to the Senate on the Telecom case.

With the handover between Italian and Iraqi troops, the Italian mission in Iraq officially comes to an end. The withdrawal of approximately 1,600 troops will take place in stages, finishing in December.

The first reading of the bill authorizing the government to revise several aspects of the Bossi-Fini law is approved in the Chamber of Deputies. FI and the UDC abstain. LN and AN vote against.

22 With the agreement of the CdL, the government approves a decree which introduces penalties for publishing wiretap transcriptions and orders the destruction of illegal wiretaps.

Piergiorgio Welby, a muscular dystrophy sufferer who is being kept alive by an artificial respirator, writes to Napolitano asking to be allowed to die.

23 Mastella authorizes an investigation into how Telecom manages wiretaps. 
In his reply to Welby, Napolitano says that there needs to be a debate on euthanasia.

25 Di Pietro demands a change in the wiretapping decree.

26 A bomb in Kabul kills an Italian soldier and injures five others. The radical left calls for Italy to withdraw from Afghanistan.

With 507 votes in favor and 20 against, the Chamber of Deputies approves the decree law authorizing the participation of Italian troops in the United Nations Interim Force in Lebanon (UNIFIL).

27 Following a meeting with government representatives, the president of the National Association of Italian City Councils (ANCI) and mayor of Florence, Leonardo Domenici, says he is unhappy with the budget plans.

The leader of the CISL, Raffaele Bonanni, says that agreement on the public workers contract is still some way off.

Speaking before the Secret Services committee investigating the Abu Omar case, General Pollari says: "The government was always informed about what was happening."

28 Prodi reports on the Telecom affair in the Chamber of Deputies. He says that he was not informed about the Rovati plan and denies that he wanted to bring the group back under state control.

29 The cabinet approves plans for a €33.5 billion budget.

\section{October}

2 Montezemolo praises the planned cuts in employer contributions, but deems the budget in general to be "demagogic" and lacking the courage to tackle public spending and waste.

Tommaso Padoa Schioppa says that modifications to the budget are possible, but that the overall balance will not change.

Epifani, CGIL's secretary, expresses his union's approval for the budget.

3 The government is defeated in the Senate in a vote on article 5 of the bill modifying the reform of the judiciary. Mastella and Di Pietro are again at loggerheads.

4 The mayors of Rome, Turin and Bologna criticize the measures affecting local administrations in the budget.

An agreement between the parties in the Senate allows a unanimous vote on the package of amendments to the Mastella law on the justice system. A compromise solution is reached between Di Pietro and Mastella.

5 Prodi reports to the Senate on the Telecom affair. The center-right calls for his resignation. 
8 Berlusconi announces rallies across the country to protest the budget.

The AN national assembly approves Fini's proposal to seek entry for the party by 2009 into the European People's Party (EPP) in the European Parliament.

9 The EU's commissioner for economic and monetary affairs, Almunia, says that "if Italy implements the budget law as presented, the deficit could fall below 3 percent of GDP in 2007."

10 The government reaches agreement with local authorities on budget cuts.

According to Francesco Staderini, president of the State Auditors Department, the budget is "askew" due to its excessive focus on revenue.

Prodi says that the airline Alitalia is now "out of control" and that it has until January to avoid bankruptcy.

11 Discussions take place within the center-left and with social partners on the budget. Padoa Schioppa warns Confindustria that it will not be possible to reduce employer contributions if employers do not accept severance pay measures.

12 At a parliamentary hearing, the governor of the Bank of Italy praises the budget's commitment to fighting tax evasion, but criticizes the fact that it is focused mainly on revenue.

A protest rally is held in Rome by the self-employed (50,000, according to the organizers) against the Visco-Bersani decree and the budget.

The cabinet approves a bill modifying television regulations.

13 Napolitano says that Ciampi's warning in 2002 about the need for pluralism in the media is still relevant.

Prodi and Pope Benedict XVI meet to discuss bioethics, the family, the right to life, and dialogue between religions.

14 Disagreements arise between the center-right and center-left over the reform of the Gasparri law (pertaining to the television industry).

16 In a meeting with the Spanish prime minister, José Luis Rodríguez Zapatero, Prodi says he supports the merger between Autostrade and Abertis.

With 186 votes in favor out of 192, Italy is voted onto the UN Security Council for the two-year term of 2007-2008.

18 In a meeting with Prodi, Napolitano calls on the government to seek dialogue with the opposition and advises caution in its use of votes of confidence.

The Senate passes the bill on the destruction of illegal wiretaps. Several amendments affecting important sections of the original text are also approved. 
The EU's competition commissioner, Neelie Kroes, says that Italy's obstruction of the Autostrade-Abertis merger contravenes EU law.

19 Standard \& Poor's and Fitch announce the downgrading of Italy's debt. Berlusconi calls on the government to resign.

20 Prodi says that the budget will be put to a vote of confidence only if the number of amendments is excessive.

21 At a CdL rally in Vicenza, Berlusconi calls Prodi "a liar" and says that Napolitano is "one of them." Casini, who did not attend the Vicenza rally, defends Napolitano and warns his allies that the fall of the Prodi government would lead not to a general election but to a "government of the willing."

Montezemolo criticizes the budget as "classist."

23 An agreement is signed between the government, Confindustria, the CGIL, the CISL, and the Unione Italiana dei Lavoratori (UIL, Italian Federation of Trade Unions) on severance pay and pension funds.

The Chamber of Deputies definitively approves the Mastella bill, which suspends and/or modifies parts of the justice reform introduced by the previous government.

24 Prodi says that the pension system reform will happen after the approval of the budget.

Four thousand amendments to the budget are presented, raising the likelihood of a vote of confidence.

Questions for a referendum abolishing parts of the electoral law are presented to the Court of Cassation.

26 The district attorney's office in Milan discovers several cases of "fiscal spying." These include illegal checks on political representatives such as Prodi and Napolitano, along with a number of other public figures.

With 327 votes in favor and 227 against, the Chamber of Deputies grants a vote of confidence on the fiscal decree linked to the budget. Protests are made in the Chamber by the CdL.

27 Napolitano says he is "taken aback" by the fiscal spying revelations. Berlusconi terms the episode "a total turkey."

Berlusconi relaunches the idea of a "grand coalition."

The CONI arbitration committee reduces the penalties imposed on Juventus, Lazio, and Fiorentina.

28 Prodi rules out the possibility of a "grand coalition," stating that his government will last the full term.

29 Berlusconi announces a protest rally against the budget, to take place on 2 December. 
30 Gangland crime in Naples appears to be spiraling out of control following a series of murders.

At a meeting in Rome, leaders from associations of artisans and shopkeepers complain that they have been left on the sidelines of the concertation process.

Berlusconi is sent for trail for subornation of the English lawyer David Mills.

31 Disagreement is expressed within the center-left over the program for the government. Chiti says "the program is not gospel." Bertinotti responds that it is binding on the issue of pensions.

Draghi, the governor of the Bank of Italy, warns that the parliamentary debate on the budget should not lead to measures detracting from its focus on economic recovery.

\section{November}

2 During a meeting of the governing parties, D'Alema complains about cuts affecting the Ministry for Foreign Affairs. The economy and finance minister agrees to make changes.

3 Amato presents his anti-crime plan in Naples.

4 Part-time workers hold a protest rally in Rome. Controversy surrounds the presence of a number of government members.

Following an agreement between the unions and the government on the public sector, the proposed strike by state workers for the end of the month is canceled.

6 Angelo Iorio of the center-right is re-elected president of the Molise region with 54 percent of the vote.

Almunia signals his approval, albeit with some reservations, for the budget.

Disagreement is expressed within both coalitions following Walter Veltroni's proposal, in an interview with the newspaper $L a$ Repubblica, for a constituent assembly on reforms.

7 Prodi urges caution regarding the possible entry of the future Democratic Party into the PES.

Storace is sent for trial along with nine others in connection with the "Laziogate" scandal.

9 The president of the university chancellors, Guido Trombetti, registers protests over planned cuts in the budget.

D'Alema says the mission in Afghanistan needs to be reassessed and expresses his concern over the situation in the country.

Storace strongly criticizes Fini, calling on him to resign as leader and convene a party congress. 
The Magistrates' Governing Council asks that an amnesty be passed so that trials whose outcomes will be struck down by the pardon bill do not have to take place.

10 The cabinet approves the decree on severance pay and national insurance, although Paolo Ferrero of RC votes against.

Senator-for-Life Rita Levi Montalcini says that she will vote against the budget if the funding cuts affecting universities and research are not withdrawn.

Rutelli presents his "liberalizations agenda" to the cabinet.

11 Controversy follows Prodi's remarks that reactions to the budget show that "we are living in a country that has gone mad and no longer thinks about the future."

12 In response to Levi Montalcini's comments, the government announces that it has allocated an extra $€ 177$ million for research. The minister for university and research, Mussi, says that this sum is largely made up of funds already in place.

15 An IMF report praises the budget, so long as it "is not subject to changes."

16 The government announces that due to the large number of amendments, the budget will be accompanied by a vote of confidence. The CdL claims that it would be unconstitutional for Senators-for-Life to swing the vote in the government's favor.

The COPACO report on the Abu Omar case accuses Pollari of having "provided false information."

17 Prodi says that his government has reversed the "dangerous trends" established by the CdL regarding spending, inequality, and tax evasion.

Iranian President Ahmadinejad writes to Prodi, who comments: "All I can say is that there is a commitment to engage in dialogue in the letter."

18 Protests by the radical left are held in Milan and Rome about the situation in the Middle East. At the demonstration in Rome, some protestors chant "10, 100, 1000 Nassiriyas" and puppets of Italian, American, and Israeli soldiers are burned. Indignation is expressed by the major institutional leaders. The CdL denounces the presence of Unione representatives at the protests.

The Chamber of Deputies approves the large set of fiscal amendments to the budget.

19 Prodi criticizes Diliberto for attending the demonstration in Rome.

The Chamber approves the 2007 budget. Berlusconi says that the budget is the product of "the ideological fundamentalism of the left" and deems it the "worst in the history of the Republic." 
Berlusconi says that he is in talks with 15 "unhappy" centerleft senators.

20 Napolitano and Pope Benedict XVI meet.

Changes are made at the top of the Secret Services. Franco Gabrielli is appointed head of the Servizio per la Informazioni e la Sicurezza Democratica (SISDE, Civilian Security and Intelligence Service), Franco Branciforte takes over at the SISMI, and Giuseppe Cucchi is to lead the Comitato Esecutivo per i Servizi di Informazione e Sicurezza (CESIS, Executive Committee for Intelligence and Security Services). The CdL complains that it was not consulted.

Two motions are presented in the run-up to the Margherita congress: one from the Rutelli wing, the other from Parisi's faction.

22 Renato Schifani (FI) calls for a constitutional reform to withdraw the right to vote of Senators-for-Life.

The Chamber of Deputies approves the fiscal decree.

Wilfred Martens, president of the European People's Party (EPP), says that AN will never be accepted into their group.

23 The Senate approves the fiscal decree.

Following the publication of a DVD by the magazine Diario alleging irregularities in the counting of blank votes, the district attorney's office in Rome opens an investigation into possible electoral fraud.

24 Controversy mounts regarding the suspected electoral fraud. Members of the CdL call for a complete recount of all ballot papers. Bertinotti says that "either way, the results stand."

25 Fini criticizes the UDC for not participating in the forthcoming center-right protest against the budget. Casini responds that the demonstration will only serve to strengthen Prodi.

26 Berlusconi is admitted to hospital after fainting during a speech to party supporters.

27 Amato opens an investigation into the Mitrokhin Commission in light of revelations that emerged following the death in London on 24 November of the former KGB colonel, Alexander Litvinenko.

28 The Pope begins his visit to Turkey, where, in a meeting with the premier, Recep Tayyip Erdogan, he expresses support for Turkish entry into the EU.

The district attorney's office in Rome investigates Enrico Deaglio, editor of Diario, for "spreading false, exaggerated, and biased information."

At a NATO summit, Italy, France, Germany, and Spain state their unwillingness to increase troop levels in Afghanistan (as requested by Bush). 
29 Disagreements arise among the political parties over the Mitrokhin Commission. Revelations emerge concerning contacts between Litvinenko and Mario Scaramella, who had been asked by Paolo Guzzanti, the president of the Mitrokhin Commission, to investigate Prodi.

The European Commission suggests that member states freeze 8 of the 35 items under discussion concerning Turkish accession.

30 The Court of Cassation quashes the sentences from the SME trial regarding Cesare Previti.

Following the revelations of telephone conversations between Guzzanti and Scaramella, Prodi says he will bring a lawsuit against those who "have infringed on my dignity as a citizen." Heated debate occurs among the political parties.

\section{December}

1 Like the Russian spy Litvinenko, the Mitrokhin Commission consultant, Mario Scaramella, finds that he too has been exposed to radioactive polonium.

The government announces that it will cede control of Alitalia.

The last Italian solders leave Iraq.

2 A center-right demonstration in Rome protests against the budget and the government. According to Berlusconi, two million people participate. Twelve thousand supporters attend the UDC rally in Palermo.

3 There are disputes within the center-right. Berlusconi calls on the UDC to return to the CdL fold as soon as possible. The UDC secretary, Lorenzo Cesa, says it is time to accept that there are two oppositions.

4 On the twelfth day of a hunger strike in support of Piergiorgio Welby's request to be allowed to die, members of the Radical Party call for a parliamentary inquiry into clandestine euthanasia.

5 During a meeting in Moscow, D’Alema asks President Vladimir Putin for full cooperation from Russia in the Litvinenko poisoning case.

The government releases details regarding the sale of its shares in Alitalia. "At least 30.1 percent" will be sold, and the buyers will be obliged to make an offer for the remaining shares.

The district attorney's office in Milan requests that Nicolò Pollari be sent for trial in connection with the Abu Omar case.

6 The committee responsible for the Senate election decides to recount all blank, void, and contested ballot papers, along with a 
selection of valid ones, from seven regions: Calabria, Campania, Lazio, Lombardy, Puglia, Sicily, and Tuscany.

The Margherita executive meets to discuss the rules for local congresses. Parisi claims that there is "a problem of legality" in the party.

8 At the seventh congress of the PES in Porto, its president, Poul Nyrup Rasmussen calls on Prodi and the future Democratic Party to join the PES. The Margherita responds negatively.

10 Epifani says that the welfare reform must not introduce an increase in the retirement age for manual workers.

12 In an interview with the Corriere della Sera, Fassino calls on the government to "pick up the pace" and commit to a program of reforms.

As a result of divisions within the Magistrates' Governing Council, Vincenzo Carbone fails to achieve a majority of votes in the election for president of the Court of Cassation.

Following a meeting with Bossi, Berlusconi announces that the CdL is about to move from being a "coalition to a federation" in order to build on the success of the 2 December protests.

13 Speaking about the budget at the assembly of the Confederation of Artisans, Prodi admits that perhaps he "gave an excessive role to the unions compared to small and medium enterprises."

Berlusconi says that the center-right will present a single list at the 2009 European Parliament elections.

At the DS national council, Fassino makes an appeal to the faction in the party opposed to the creation of the Democratic Party and expresses the hope that schisms do not occur. He reassures those present that "the Democratic Party will not be a weak party."

The boards of Autostrade and Abertis announce that they have "reached the common conclusion that it is impossible to proceed with the merger."

14 The committee responsible for the Chamber of Deputies election decides to re-examine 10 percent of the ballot papers.

The State Auditors Department criticizes the inclusion in the set of amendments to the budget of a paragraph that would allow the statute of limitations to be applied to accounting fraud committed by public administrators. As it cannot propose changes in Parliament, the government assures that it will cancel the paragraph with a decree. Berlusconi accuses the center-left of "making ad personam laws to help its local administrators."

15 The Senate passes a vote of confidence on the budget. The CdL criticizes the Senators-for-Life, whose votes prove crucial to the outcome. 
16 A court in Rome deems inadmissible Welby's appeal for his medical treatment to be stopped as the legal system makes no provision for this.

Casini says that "after Prodi, we will need a government of the willing, which can consider the future of the country without having to bow to vetoes from extreme factions."

18 Confindustria's think tank claims that the budget could have detrimental effects on the GDP. Padoa Schioppa criticizes the findings, asserting that Confindustria has behaved "like a political party."

Napolitano reprimands the government for the methods used to approve the budget. He says that the use of a vote of confidence on a single article "containing an abnormal number of measures" is taking "a legislative practice to the extreme and is beyond the comprehension of public opinion."

21 The Chamber of Deputies definitively approves the budget and, with a vote of confidence, passes the large set of amendments presented by the government.

22 With a unanimous vote, the Federal Council of the Margherita approves the withdrawal of motion number 2 (by Parisi) and the reformulation of motion number 1 . A single congress will be held.

27 A decree approved by the government and signed by Napolitano cancels the paragraph that changed the statute of limitations for accounting fraud.

28 In his end-of-year press conference, Prodi says that now the government has put the accounts that "had been compromised by the previous government" back on an even keel: "2007 will be the year in which we turn the corner." Berlusconi replies that "it is politically and morally wrong to blame previous governments for your own actions."

29 Six members of the promotional committee for the electoral law referendum, including Franco Bassanini, tender their resignations. They complain that the view that there can be no parliamentary modifications to texts that are passed by the referendum has become predominant within the committee.

30 Following pressure from Napolitano, the judge Vincenzo Carbone (in dispute with the Magistrates' Governing Council regarding his nomination to the Court of Cassation) says that he will not preside over the official opening of the legal year on 26 January 2007.

31 In his end-of-year address, Napolitano calls for greater dialogue among the political parties and says that agreements on reform should be constructed by showing "realism and restraint." 
